\title{
Yeasts isolated from tropical fruit ice creams: diversity, antifungal susceptibility and adherence to buccal epithelial cells
}

\author{
Leveduras isoladas de sorvetes de frutas tropicais: diversidade, \\ susceptibilidade a antifúngicos e adesão a células epiteliais \\ bucais
}

Gabriella Breder Lara Lima1, Carlos Augusto Rosa1, Susana Johann', Mariana de Lourdes Almeida Vieira² ${ }^{2}$ Fátima de Cássia Oliveira Gomes²* (1)

${ }^{1}$ Universidade Federal de Minas Gerais (UFMG), Instituto de Ciências Biológicas, Departamento de Microbiologia, Belo Horizonte/MG - Brasil

${ }^{2}$ Centro Federal de Educação Tecnológica de Minas Gerais (CEFET-MG), Departamento de Química, Belo Horizonte/MG - Brasil

*Corresponding Author: Fátima de Cássia Oliveira Gomes, Centro Federal de Educação Tecnológica de Minas Gerais (CEFET-MG), Departamento de Química, Av. Amazonas, 5253, Nova Suíça, CEP: 30421-169, Belo Horizonte/MG - Brasil, e-mail: fatimaog@cefetmg.br

Cite as: Lima, G. B. L., Rosa, C. A., Vieira, M. L. A., \& Gomes, F. C. O. (2019). Yeasts isolated from tropical fruit ice creams: diversity, antifungal susceptibility and adherence to buccal epithelial cells. Brazilian Journal of Food Technology, 22, e2018197. https://doi.org/10.1590/1981-6723.19718.

\begin{abstract}
Fruit-based ice creams are products widely consumed in tropical countries and, because of their composition, can be a good source for microbial growth, including opportunistic pathogens. The aims of this study were to characterize the yeast populations present in Brazilian fruit-based ice creams, and to investigate the antifungal susceptibility to amphotericin $B$, fluconazole and itraconazole, and the ability of the isolates that were able to grow at $37^{\circ} \mathrm{C}$ to adhere to buccal epithelial cells (BEC). Two hundred and sixty-seven yeast isolates obtained from the ice cream samples were identified as belonging to 29 species, with counts that ranged from 1.5 to $5.2 \log \mathrm{CFU} / \mathrm{mL}$. The predominant species were Candida intermedia, Torulaspora delbrueckii, C. parapsilosis, Clavispora lusitaniae, Saccharomyces cerevisiae and Pichia kudriavzevii. At least 16 yeast species isolated in this study have been reported as opportunistic pathogens. Forty-one yeast isolates showed resistance or dose-dependent susceptibility to at least one of the antifungal drugs tested. One isolate of $C$. parapsilosis was resistant to all the antifungals tested and showed ability to adhere to BEC. The percentage of adhesion to BEC was high mainly for isolates of $P$. kudriavzevii, Meyerozyma guilliermondii, C. parapsilosis, S. cerevisiae and Debaromyces hansenii. The data suggest that the presence of these opportunistic yeasts as contaminants in ice creams may represent a potential risk to the final consumer, especially to immunocompromised individuals who may consume these products.
\end{abstract}

Keywords: Yeast occurrence; Ice creams samples; Antifungal activity; Adhesion; Pathogens; Opportunistic microorganisms. 


\section{Resumo}

Os sorvetes à base de frutas são produtos amplamente consumidos em países tropicais e, devido à sua composição, podem ser uma boa fonte de crescimento microbiano, incluindo patógenos oportunistas. Os objetivos deste estudo foram caracterizar as populações de leveduras presentes nos sorvetes brasileiros à base de frutas e investigar sua susceptibilidade aos antifúngicos anfotericina $B$, fluconazol e itraconazol, e a capacidade dos isolados, que puderam crescer a $37{ }^{\circ} \mathrm{C}$, de aderir em células epiteliais bucais. Duzentos e sessenta e sete isolados de levedura obtidos das amostras de sorvete foram identificados como pertencentes a 29 espécies, com contagens variando de 1,5 a 5,2 log UFC/mL. As espécies predominantes foram Candida intermedia, Torulaspora delbrueckii, C. parapsilosis, Clavispora lusitaniae, Saccharomyces cerevisiae e Pichia kudriavzevii. Pelo menos 16 espécies de leveduras isoladas neste estudo foram relatadas como agentes patogênicos oportunistas. Quarenta e um isolados de leveduras apresentaram resistência ou susceptibilidade dose-dependente a pelo menos um dos antifúngicos testados. Um isolado de C. parapsilosis foi resistente a todos os antifúngicos testados e mostrou capacidade de aderir a células epiteliais bucais. A porcentagem de adesão foi alta principalmente para isolados de $P$. kudriavzevii, Meyerozyma guilliermondii, C. parapsilosis, S. cerevisiae e Debaromyces hansenii. Os dados sugerem que a presença dessas leveduras oportunistas como contaminantes nos sorvetes pode representar um risco para o consumidor final, especialmente para indivíduos imunocomprometidos que podem consumir esses produtos.

Palavras-chave: Ocorrência de leveduras; Amostras de sorvetes; Atividade antifúngica; Adesão; Patógenos; Microrganismos oportunistas.

\section{Introduction}

Ice cream is a major product of the dairy industry and is widely consumed in tropical countries due to the high temperatures in these regions (Farias et al., 2006; Arbuckle, 2013; Lima et al., 2016). It is prepared by freezing a mixture of pasteurized milk products (milk, condensed milk, milk powder and cream), sugar, emulsifiers, stabilisers, flavouring and colouring agents, which are combined in a desirable proportion (Ahmed et al., 2009; Lee et al., 2009; Ambily \& Beena, 2012). Ice creams, usually made from dairy products, are often combined with fruits. In Brazil, tropical fruits that are commonly used in the preparation of fruitbased ice cream include mango, pineapple, passion fruit, strawberry and guava. Fruit-based ice creams are especially susceptible to yeast contamination since the unprocessed fruit pulps used in the ice cream preparation frequently have high counts of these microorganisms (Trindade et al., 2002). The high content of nutrients like lactose, sugar and proteins, and the final $\mathrm{pH}$, make them an excellent growth medium for yeasts, even though stored at low temperatures (Lee et al., 2009; Ambily \& Beena, 2012). These products may represent a specialised ecological environment for the selective occurrence and growth of certain yeast species, such as Debaryomyces hansenii (=Candida famata), Naganishia albida (=Cryptococcus albidus), Saitozyma flava (=Cryptococcus flavus), Rhodosporidium glutinis (=Rhodotorula glutinis) and Rhodotorula mucilaginosa, which have been isolated from ice creams (Fleet \& Mian, 1987).

The presence of pathogens may cause serious disease outbreaks in humans who consume contaminated ice cream (Jadhav \& Raut, 2014; Lima et al., 2016). The consumption of contaminated ice creams has led to fungal outbreaks in Asia, Europe and North America (Chugh, 1996; Djuretic et al., 1997; Jadhav \& Raut, 2014). In Brazil, the relatively simple manufacturing process, combined with a lack of obligation to register the product, has increased the number of factories characterised by deficient sanitary-hygienic practices (Lima et al., 2016). Moreover, the use of unprocessed fruit and the absence of thermal treatment contribute to the presence of pathogens in the product (Jadhav \& Raut, 2014; Lima et al., 2016).

The consumption of contaminated foods can be a risk to vulnerable age groups, such as children and elderly people, and also to immunosuppressed patients. Hence, it is necessary to maintain a high microbiological safety standard in these products (Kanbakan et al., 2004). In addition, the presence of high counts of yeast species that are not included in the microorganisms specified by the Brazilian sanitary 
legislation, may represent a risk to consumers, since many of these species have been reported as spoilage microorganisms or opportunistic pathogens (Kurtzman et al., 2011; Maciel et al., 2013). Low pH values (3.5-5.5) and high sugar levels are factors that can promote the development of yeasts in ice creams (Lima et al., 2016). The yeast species found in food are almost entirely non-pathogenic (Tribst et al., 2009; Sundh \& Melin, 2011; Maciel et al., 2013). However, opportunistic pathogenic species including Candida parapsilosis and Pichia kudriavzevii (formerly C. krusei) have been isolated from food and beverages (Stratford, 2006; Sundh \& Melin, 2011; Maciel et al., 2013). Environmental strains of opportunistic yeast species can be resistant to antifungal drugs and could be a risk to consumers (Brilhante et al., 2013; Maciel et al., 2013). The adhesion of the pathogenic yeasts to host cells or abiotic surfaces is considered an important virulence factor and is essential for colonisation and survival in the host (Johann et al., 2007; Höfs et al., 2016).

The aim of this study was thus to characterise the yeast communities present in tropical fruit-based ice creams obtained from the Brazilian market. In addition, the antifungal resistance of the species able to grow at $37^{\circ} \mathrm{C}$ was investigated, which could be considered a prerequisite phenotype for invasive mycoses (Perfect, 2006), and the ability of these yeasts to adhere to buccal epithelial cells (BEC) was also tested.

\section{Material and methods}

\subsection{Sample collection and yeast isolation}

Fifty-one fruit-based ice cream samples were obtained from seven commercial establishments with industrial production and seven with artisanal production. The fruit-based ice cream samples obtained included 12 pineapple (Ananas comosus), 11 açaí (the Amazon fruit Euterpe oleracea), five guava (Psidium guajava), nine mango (Mangifera indica) and 14 passion fruit (Passiflora edulis) ice creams. The samples were obtained in the municipality of Belo Horizonte, Minas Gerais state, Brazil, from July 2010 to January 2011. They were placed in disposable plastic cups that were provided by the establishments and then immediately transferred to sterile flasks, transported to the laboratory in isothermal packaging and examined within 24 hours.

Aliquots $(10 \mathrm{~mL})$ of each sample were diluted in $90 \mathrm{~mL}$ sterile $0.1 \%$ buffered peptone water before inoculation. To determine the yeast population counts, triplicate aliquots $(0.1 \mathrm{~mL})$ of appropriate decimal dilutions were spread on yeast extract-malt extract agar (YMA; $1 \%$ glucose, $0.5 \%$ peptone, $0.3 \%$ malt extract, $0.3 \%$ yeast extract, $2 \%$ agar) supplemented with $10 \mathrm{mg} \%$ chloramphenicol. The plates were incubated at $25{ }^{\circ} \mathrm{C}$ for 3 to 10 days. After growth, the different yeast morphotypes were enumerated and representative colonies of each morphotype were purified by repeated streaking on YMA plates. The purified samples were maintained at $-80{ }^{\circ} \mathrm{C}$ prior to identification.

\subsection{Yeast identification}

The yeasts were characterised morphologically and physiologically by standard methods (Kurtzman et al., 2011). Growth at $37^{\circ} \mathrm{C}$ was assessed on glucose-yeast nitrogen base agar and the results recorded after 4 days (Kurtzman et al., 2011). Isolates with identical morphological and physiological characteristics were grouped together and subjected to PCR fingerprinting using the primer EI1 (5'-CTGGCTTGGTGTATGT-3') (Lopes et al., 1998). Yeast strains with identical PCR fingerprint patterns were grouped together and putatively considered to belong to the same species (Lopes et al., 1998; Canelhas et al., 2011). At least 50\% of the yeast isolates of each molecular group were identified by sequencing of the internal transcribed spacer (ITS)-5.8S region and the D1/D2 variable domains of the large subunit of the rRNA gene, as described previously (Lachance et al., 1999). The amplified DNA was concentrated, cleaned, and sequenced in an ABI 3130 Genetic Analyzer automated sequencing system using BigDye v3.1 and the POP7 polymer. The sequences obtained were compared with those 
in the GenBank database using the Basic Local Alignment Search Tool - BLAST (National Center for Biotechnology Information, 2018; Altschul et al., 1997).

\subsection{Antifungal drug susceptibility}

Yeast susceptibility to amphotericin B (Sigma, USA), itraconazole (Jansen Pharmaceutical, Belgium) and fluconazole (Pfizer Pharmaceutical, USA) was determined for the isolates able to grow at $37{ }^{\circ} \mathrm{C}$. The determinations were made using the broth microdilution method in accordance with the Clinical Laboratory Standards Institute protocol M27-A3 (Clinical and Laboratory Standards Institute, 2008). Yeast suspensions were prepared by the spectrophotometric method, with a final inoculum of $(1.5 \pm 1.0) \times 10^{3} \mathrm{cells} / \mathrm{ml}$. A $100 \mu \mathrm{L}$ aliquot of yeast suspension was added to each well of the microdilution trays. The final concentrations of fluconazole ranged from 0.125 to $64 \mu \mathrm{g} / \mathrm{mL}$ and the final concentrations of itraconazole and amphotericin B ranged from 0.031 to $16 \mu \mathrm{g} / \mathrm{mL}$. The plates were incubated at $35{ }^{\circ} \mathrm{C}$ and the minimum inhibitory concentration (MIC) endpoints were read visually after 24 and $48 \mathrm{~h}$. Drug and yeast-free controls were included in all the experiments.

After incubation, the MICs of amphotericin B were read as the lowest concentration at which no cell growth was visualised. The MICs of the other drugs were read as the lowest concentration at which a prominent decrease (approximately $80 \%$ ) in turbidity relative to that in the control well was observed. The reference values used for the susceptibility tests in vitro $(\mu \mathrm{g} / \mathrm{mL})$ were those published by Clinical and Laboratory Standards Institute (2008).

\subsection{Yeast adhesion to BEC}

Yeast cells were suspended at $10^{6}$ cells $/ \mathrm{mL}$ in a $1 \mathrm{~mL}$ volume for each yeast isolate and $4 \mathrm{~mL}$ of Sabouraud dextrose broth subsequently added. These samples were incubated at $37^{\circ} \mathrm{C}$ for 1 hour with agitation at $120 \mathrm{rpm}$, and then centrifuged for 10 minutes at $3,000 \times \mathrm{g}$, washed twice with PBS and finally suspended in $3 \mathrm{~mL}$ of PBS.

The method described by Kimura \& Pearsall (1978) and Ellepola \& Samaranayake (1998a, b), and modified by Johann et al. (2007), was used in the preparation of buccal epithelial cells (BECs) for the adherence assays. To this end, BECs from healthy adults were collected in the morning with the aid of sterile swabs and dispensed in $10 \mathrm{~mL}$ of PBS. The BEC suspensions were washed four times with PBS and collected by centrifugation at $3,000 \times \mathrm{g}$ for 10 minutes before being resuspended in PBS at a final concentration of $10^{5} \mathrm{cell} / \mathrm{s} / \mathrm{mL}$. Once prepared, $0.5 \mathrm{~mL}$ of BEC suspension and $0.5 \mathrm{~mL}$ of yeast suspension were mixed gently and incubated in a rotary shaker at $37^{\circ} \mathrm{C}$ for $1 \mathrm{~h}$. At the end of this period, each solution containing BEC was filtered through polycarbonate filters (pore size $12 \mu \mathrm{m}$ ), washed with $100 \mathrm{~mL}$ of PBS to remove non-adhered yeasts and the filters placed on glass slides. The preparations were air-dried, fixed with heat, stained with crystal violet and the yeasts adhered to the buccal cells counted under a light microscope $(\times 40)$. For each slide, 50 BEC were evaluated and the number of associated yeast cells counted. Clumped, folded or overlapping BECs were excluded.

\section{Results and discussion}

Two hundred and sixty-seven yeast isolates belonging to 29 species were isolated from the fruit-based ice creams. The yeast populations ranged from 1.5 to $5.2 \log$ colony forming units $(\mathrm{CFU}) / \mathrm{mL}$. Table 1 details the occurrence of yeasts in the ice creams analysed in the present study. 
Table 1. Yeast species counts $(\mathrm{CFU} / \mathrm{mL})$ and the number of positive samples isolated from ice creams made with fruit juices or fruit pulps.

\begin{tabular}{|c|c|}
\hline Yeast species & Ice $\operatorname{cream}(n=51)$ \\
\hline Aureobasidium pullulans & $1.5-1.8(8)$ \\
\hline Candida akabanensis (Metschnikowia clade) & $3.1(1)$ \\
\hline C. etchellsii (Starmerella clade) & $5.2(1)$ \\
\hline C. intermedia (Metschnikowia clade) & $1.5-5.2(28)$ \\
\hline C. orthopsilosis (C. albicans/Lodderomyces clade) & $3.22(1)$ \\
\hline C. pararugosa (Wickerhamiella clade) & $3-4(9)$ \\
\hline C. parapsilosis (C. albicans/Lodderomyces clade) & $1.82-4.63(17)$ \\
\hline C. quercitrusa (Kurtzmaniella clade) & $1.8(1)$ \\
\hline C. sake (C. albicans/Lodderomyces clade) & $4.1(1)$ \\
\hline Clavispora lusitaniae & $3.2-4.6(15)$ \\
\hline Papiliotrema flavescens & $3.3-4.4(2)$ \\
\hline Pa. laurentii & $1.5(1)$ \\
\hline Debaryomyces hansenii & $1.5-4(4)$ \\
\hline Meira argovae & $1.5(1)$ \\
\hline Meyerozyma guilliermondii & $3.7-4.1(2)$ \\
\hline Pichia kudriavzevii & $1.5-3.6(10)$ \\
\hline P. manshurica & $1.5-1.9(2)$ \\
\hline P. membranifaciens & $1.5(1)$ \\
\hline P. norvegensis & $4.0(1)$ \\
\hline P. occidentalis & $3.2(1)$ \\
\hline Rhodotorula mucilaginosa & $1.5-3.5(3)$ \\
\hline Saccharomyces cerevisiae & $1.5-4.9(14)$ \\
\hline Torulaspora delbrueckii & $1.5-4.8(26)$ \\
\hline Trichosporon faecal & $1.5(1)$ \\
\hline Trichosporon ovoides & $3.1-4.4(4)$ \\
\hline Trichosporon $\mathrm{sp}$. & $1.5(2)$ \\
\hline Wickerhamomyces anomalus & $1.8(1)$ \\
\hline Zygoascus hellenicus & $3.5(1)$ \\
\hline Zygosaccharomyces bailii & $3.2-3.8(2)$ \\
\hline
\end{tabular}

n: number of samples; ( ) number of samples in which the species was isolated.

The prevalent yeast species isolated from the ice creams were Candida intermedia, Torulaspora delbrueckii, C. parapsilosis, Clavispora lusitaniae, Saccharomyces cerevisiae and Pichia kudriavzevii. Most of these can be considered as spoilage agents and have been isolated from beverages and foods (Trindade et al., 2002; Tribst et al., 2009; Kurtzman et al., 2011; Maciel et al., 2013). Thirteen yeast species occurred only in one ice cream sample and could be considered as accidental contaminants of these products. These species were C. akabanensis, C. etchellsii, C. orthopsilosis, C. quercitrusa, C. sake, Papiliotrema laurentii, Meira argovae, P. membranifaciens, P. norvegensis, P. occidentalis, Trichosporon faecale, Wickerhamomyces anomalus and Zygoascus hellenicus. Some of these yeasts can be found associated with flowers, fruits, plant surfaces and insects (Kurtzman et al., 2011). Yeast contamination of ice creams can be caused by inappropriate storage and handling conditions or associated with the fruit pulps used in the preparation of these foods.

At least 16 yeast species isolated in this study have been reported as opportunistic pathogens (Miceli et al., 2011; Maciel et al., 2013; Taj-Aldeen et al., 2014). Candida intermedia, C. orthopsilosis, C. pararugosa, C. quercitrusa, C. sake, P. kudriavzevii, Cl. lusitaniae, and W. anomalus have been associated with lifethreatening infections in immunocompromised hosts (Kurtzman et al., 2011; Miceli et al., 2011; Maciel et al., 2013; Taj-Aldeen et al., 2014; Oliveira et al., 2014; Westblade et al., 2015; Fernández-Ruiz et al., 2017) and hence their detection in the ice cream samples could indicate a risk to consumers in Brazil. C. parapsilosis is the third most common Candida species in Brazil which causes invasive fungal infections (Colombo et al., 2006). S. cerevisiae and Pa. laurentii (former Cr. laurentii), which were both found in ice creams in this 
study, may act as opportunistic agents and cause infections in their hosts (Anoop et al., 2015; Thomson et al., 2017; Martínez et al., 2017).

Considering that many of the yeasts found in the present study are species with several reports of systemic disease, mainly in immunocompromised patients, it was of interest to examine the yeast isolates for indications that they may really pose a threat to human health. For this reason, 68 yeast isolates obtained from ice cream samples that were able to grow at $37^{\circ} \mathrm{C}$, were tested to determine their susceptibility to the antifungal agents fluconazole, itraconazole and amphotericin B (Table 2). The capacity of the yeast isolates that were resistant or displayed a dose-dependent susceptibility to the antifungal agents to adhere to BEC was also tested, since adherence is an essential step in fungal pathogenesis and is an important virulence factor of pathogenic yeasts (Table 3) (Johann et al., 2007; Costa et al., 2012).

Table 2. Minimum inhibitory concentrations $(\mu \mathrm{g} / \mathrm{mL})$ of fluconazole, itraconazole and amphotericin B against fruit ice cream yeast isolates able to grow at $37^{\circ} \mathrm{C}$.

\begin{tabular}{|c|c|c|c|c|}
\hline \multirow{2}{*}{ Yeast species } & \multirow{2}{*}{$\frac{\text { Ice cream made with fruit juices or pulps }}{(n=79)^{\mathrm{a}}}$} & \multirow{2}{*}{$\begin{array}{c}\text { Fluconazole } \\
(\mu \mathrm{g} / \mathrm{mL})\end{array}$} & \multirow{2}{*}{$\frac{\text { Itraconazole }}{(\mu \mathrm{g} / \mathrm{mL})}$} & \multirow{2}{*}{$\frac{\text { Amphotericin B }}{(\mu \mathrm{g} / \mathrm{mL})}$} \\
\hline & & & & \\
\hline Candida etchellsii & 1 & $0.5(1-0-0)^{\mathrm{b}}$ & $0.031(1-0-0)$ & $0.031(1-0-0)$ \\
\hline C. intermedia & 10 & $0.25-4(10-0-0)$ & $0.031-0.125(10-0-0)$ & $0.031-0.5(10-0-0)$ \\
\hline C. parapsilosis & 13 & $0.25-\geq 64(11-0-2)^{*}$ & $0.031-16(11-1-1)^{*}$ & $0.25-16(10-0-3)^{*}$ \\
\hline C. pararugosa & 5 & $0.125-8(5-0-0)$ & $0.031-0.062(5-0-0)$ & $0.031-2(4-0-1)^{*}$ \\
\hline C. sake & 1 & $0.25(0-0-1)^{*}$ & $0.031(1-0-0)$ & $0.031(1-0-0)$ \\
\hline Clavispora lusitaniae & 10 & $0.25-1(10-0-0)$ & $0.031-0.125(9-0-1)^{*}$ & $0.125-8(9-0-1)^{*}$ \\
\hline Debaryomyces hansenii & 3 & $1-2(3-0-0)$ & $0.031-0.062(3-0-0)$ & $1-2(1-0-2)^{*}$ \\
\hline Meyerozyma guilliermondii & 2 & $1-4(2-0-0)$ & $0.5(0-0-2)^{*}$ & $0.5-2(1-0-1)^{*}$ \\
\hline Pichia kudriavzevii & 3 & $32-64(0-2-1)^{*}$ & $0.25-0.5(0-3-0)^{*}$ & $2-16(0-0-3)^{*}$ \\
\hline P. manshurica & 1 & $64(0-0-1)^{*}$ & $0.062(1-0-0)$ & $16(0-0-1)^{*}$ \\
\hline P. norvegensis & 1 & $32(0-1-0)^{*}$ & $0.125(1-0-0)$ & $1(1-0-0)$ \\
\hline P. occidentalis & 1 & $0.125(1-0-0)$ & $0.5(0-1-0)^{*}$ & $0.031(1-0-0)$ \\
\hline Saccharomyces cerevisiae & 11 & $0.5-16(10-1-0)^{*}$ & $0.031-4(5-0-6)^{*}$ & $0.031-1(9-0-2)^{*}$ \\
\hline Torulaspora delbrueckii & 14 & $2-64(13-0-1)^{*}$ & $0.031-0.125(14-0-0)$ & $0.031-0.5(14-0-0)$ \\
\hline Trichosporon ovoides & 1 & $0.125(1-0-0)$ & $0.031(1-0-0)$ & $0.062(1-0-0)$ \\
\hline Trichosporon sp. & 1 & $2(1-0-0)$ & $0.125(1-0-0)$ & $1(1-0-0)$ \\
\hline Wickerhamomyces anomalus & 1 & $64(0-0-1)^{*}$ & $1(0-0-1)^{*}$ & $0.25(1-0-0)$ \\
\hline
\end{tabular}

${ }^{a}$ The number of yeast isolates tested. ${ }^{\text {b}}$ The first number in parenthesis represents the number of susceptible isolates; the second number represents the number of dose-dependent susceptible isolates; the third number represents the number of resistant isolates. *Species that showed resistance or dose-dependent susceptible isolates are shown with asterisks.

Table 3. Adhesion of the yeast isolates from ice creams to buccal epithelial cells.

\begin{tabular}{cccc}
\hline Yeast species* & $\begin{array}{c}\text { Number of adherent } \\
\text { yeast cells }\end{array}$ & $\begin{array}{c}\text { Percentage of } \\
\text { adhesion (\%) }\end{array}$ & $\begin{array}{c}\text { Dose-dependent } \\
\text { susceptibility to }\end{array}$ \\
\hline Candida parapsilosis (3) & $7-10$ & $22.5-32.2$ & $\begin{array}{c}\text { Amphotericin B, Fluconazole, } \\
\text { Itraconazole }\end{array}$ \\
C. sake (1) & 2 & 6.4 & Fluconazole \\
C. pararugosa (1) & 2 & 6.4 & Amphotericin B \\
Clavispora lusitaniae (1) & 6 & 19.3 & Amphotericin B, Itraconazole \\
Debaryomyces hansenii (1) & 8 & 25.8 & Amphotericin B \\
Meyerozyma guilliermondii (1) & 11 & 35.4 & Amphotericin B, Itraconazole \\
Pichia kudriavzevii (2) & $2-14$ & $6.4-45.1$ & Amphotericin B, Fluconazole \\
\hline P. manshurica (1) & 1 & 3.2 & Fluconazole, Itraconazole \\
\hline Saccharomyces cerevisiae (5) & $1-9$ & $3.2-29.0$ & Itraconazole, Amphotericin B \\
Wickerhamomyces anomalus (1) & 5 & 16.1 & Fluconazole, Itraconazole \\
\hline
\end{tabular}

*Number in parenthesis represents the number of yeast isolates tested.

Nearly all the yeasts obtained from the fruit ice creams were susceptible to fluconazole, except isolates of C. sake, C. parapsilosis, P. kudriavzevii, P. manshurica, P. norvegensis, T. delbrueckii and W. anomalus, 
which were resistant to this antifungal agent and presented MIC values that ranged from 0.25 to $64 \mu \mathrm{g} / \mathrm{mL}$ (Table 2). One isolate of P. kudriavzevii, resistant to fluconazole, presented the highest percentage of adhesion to BEC (45.1\%). This isolate was also resistant to amphotericin B (Table 3).

Resistance to itraconazole was observed in 11 isolates belonging to the species C. parapsilosis, Cl. lusitaniae, M. guilliermondii, S. cerevisiae and $W$. anomalus, with MIC values ranging from 0.031 to $16 \mu \mathrm{g} / \mathrm{mL}$ (Table 2). One isolate of C. parapsilosis and two isolates of $P$. kudriavzevii were susceptible to itraconazole in a dose-dependent manner, and showed adhesion rates of $32.2 \%$ and $45.1 \%$, respectively, to BEC (Table 3).

Fourteen isolates displayed resistance to amphotericin B, identified as C. parapsilosis $(\mathrm{n}=3)$, C. pararugosa $(\mathrm{n}=1), C$. lusitaniae $(\mathrm{n}=1), D$. hansenii $(\mathrm{n}=2)$, M. guilliermondii $(\mathrm{n}=1), P$. kudriavzevii $(\mathrm{n}=3)$, $P$. manshurica $(\mathrm{n}=1)$ and $S$. cerevisiae $(\mathrm{n}=2)$, with MIC values ranging from 0.125 to $16 \mu \mathrm{g} / \mathrm{mL}$. None of the isolates obtained from ice creams showed dose-dependent susceptibility to amphotericin B.

In summary, 41 yeast isolates from ice creams exhibited resistance or dose-dependent susceptibility to at least one of the antifungal drugs tested (Table 2). One isolate of C. parapsilosis (SL.17.7) was resistant to all three anti-fungal agents and was also able to adhere to BEC (adherence rate of 25.5\%) (Table 3). C. parapsilosis is an opportunistic commensal responsible for various mycoses (Miceli et al., 2011). The finding of antifungal-resistant strains of $C$. parapsilosis is particularly interesting, because it is the third most frequent agent of candidemia in Brazil (Colombo et al., 2006). Trofa et al. (2008) and Pinhati et al. (2016) also reported that $C$. parapsilosis is an emerging human pathogen that has dramatically increased in significance and prevalence over the past three decades, becoming one of the leading causes of invasive candidiasis worldwide. Individuals at highest risk for severe yeast infections include neonates and patients in intensive care units, as well as patients with cancer and neutropenia (Trofa et al., 2008; Pinhati et al., 2016; Villalobos et al., 2016). Although it is difficult to evaluate the risk associated with the consumption of contaminated food, the presence of many strains with varying susceptibility to the three commonly used antifungal drugs suggests a potential threat to consumers such as immunocompromised individuals, who consume these products.

Only a few classes of antifungal drugs are available, so the emergence of resistance to single drug classes and to multidrug resistance greatly hampers patient management. The mechanisms of antifungal drug resistance are mostly shared by both resistant strains displaying inherently reduced susceptibility and by those acquiring resistance during therapy. The molecular mechanisms that cause drug resistance are naturally occurring in less susceptible species and are acquired in strains of susceptible organisms. These mechanisms include altered drug affinity and target abundance, reduced intracellular drug levels mediated by efflux transporters, and permeability barriers associated with biofilms. Genetic factors regulating these mechanisms, as well as cellular factors important for stress adaptation, are also important to better understand the emergence of antifungal drug resistance (Cowen et al., 2014).

The adherence to BEC, which was highest for P. kudriavzevii isolates, followed by M. guilliermondii, C. parapsilosis, S. cerevisiae and D. hansenii, is an important factor that can be evaluated. Successful colonisation and infection by a microorganism often depends on the initial capacity to adhere to host tissues (Trofa et al., 2008). The production of enzymes and the ability to adhere to epithelial and endothelial cells have been studied thoroughly as virulence factors in opportunistic Candida species and in other groups of yeasts. The adhesion of micro-organisms to host mucosal surfaces is a prerequisite for colonization and infection (Lyon \& Resende, 2006). The presence of these yeasts as contaminants in ice creams may represent a risk to consumers.

Finally, the results suggest that fruit-based ice creams may represent a potential risk to consumers in Brazil, especially to vulnerable age groups and immunosuppressed patients. It is difficult to evaluate the risk associated with the consumption of contaminated food. Yeast contaminants that can affect the ice cream quality may also represent a risk to humans, and may have originated from poorly sanitized equipment, 
contaminated water and other raw materials, combined with the absence of an appropriate thermal treatment. These microorganisms may act as opportunistic pathogens and cause serious infections in humans (Kurtzman et al., 2011; Miceli et al., 2011; Maciel et al., 2013; Taj-Aldeen et al., 2014; Oliveira et al., 2014; Westblade et al., 2015; Fernández-Ruiz et al., 2017). In Brazil, the lack of sanitary inspection and obligation to register this kind of product has increased the number of factories with deficient sanitary-hygienic practices.

\section{Conclusion}

The results led to the characterization of the yeast communities present in tropical fruit-based ice creams obtained on the Brazilian market. In addition, yeast species that may be considered pathogenic microorganisms were isolated. The presence of pathogenic yeasts resistant to the three most commonly used antifungal drugs represents a potential threat to the consumer. These findings also suggest that sanitary rules and hygienic practices have not been properly adopted during the manufacturing, transport and storage stages of the products analysed. Thus this work provides an alert to the potential risk posed by these frozen products to public health.

\section{References}

Ahmed, K., Hussain, A., Imran, Ali Qazalb, M., \& Hussain, W. (2009). Microbiological quality of ice cream sold in Gilgit town. Pakistan Journal of Nutrition, 9(9), 1397-1400. http://dx.doi.org/10.3923/pjn.2009.1397.1400

Altschul, S. F., Madden, T., Schaffer, A., Zhang, J., Zhang, Z., Miller, W., \& Lipman, D. (1997). Gapped BLAST and PSI-BLAST: a new generation of protein database search programs. Nucleic Acids Research, 25(17), 3389-3402. PMid:9254694. http://dx.doi.org/10.1093/nar/25.17.3389

Ambily, R., \& Beena, A. K. (2012). Bacteriological quality of ice cream marketed in Thrissur town, Kerela, India. Veterinary World, 5(12), 738-741. http://dx.doi.org/10.5455/vetworld.2012.738-741

Anoop, V., Rotaru, S., Shwed, P., Tayabali, A. F., \& Arvanitakis, G. (2015). Review of current methods for characterizing virulence and pathogenicity potential of industrial Saccharomyces cerevisiae strains towards humans. FEMS Yeast Research, 15(6), 1524-1533. PMid:26195617. http://dx.doi.org/10.1093/femsyr/fov057

Arbuckle, W. S. (2013). Ice cream (4th ed.). New York: Springer Science Business Media.

Brilhante, R. S., Alencar, L. P., Cordeiro, R., Castelo-Branco, S., Teixeira, C. E., Macedo, R., Lima, D. T., Paiva, M. A., Monteiro, A. J., Alves, N. D., Oliveira, M.F., Sidrim, J. J., Rocha, M. F., Bandeira, T. J., \& Rodrigues, T. (2013). J. Detection of Candida species resistant to azoles in the microbiota of rheas (Rhea americana): possible implications for human and animal health. Journal of Medical Microbiology, 62(6), 889-895. PMid:23493027. http://dx.doi.org/10.1099/jmm.0.055566-0

Canelhas, M. R., Barbosa, A. C., Medeiros, A. O., Lee, C. F., Huang, L. Y., Lachance, M. A., \& Rosa, C. A. (2011). Saturnispora serradocipensis sp nov. and Saturnispora gosingenis sp nov., two ascomycetous yeasts from ephemeral habitats. Antonie van Leeuwenhoek, 99(2), 241-247. PMid:20607403. http://dx.doi.org/10.1007/s10482-010-9482-9

Chugh, K. (1996). Salmonella outbreak from ice cream. Indian Pediatrics, 33(11), 976-977. PMid:9141842.

Clinical and Laboratory Standards Institute - CLSI. (2008). Reference method for broth dilution antifungal susceptibility testing of yeast (3rd Informational Supplement CLSI Document; M27-S3). Waine: Clinical and Laboratory Standard Institute.

Colombo, A. L., Nucci, M., Park, B. J., Nouér, S. A., Arthington-Skaggs, B., Da Matta, D. A., Warnock, D., Morgan, J., \& Brazilian Network Candidemia Study. (2006). Epidemiology of candidemia in Brazil: a nationwide sentinel surveillance of candidemia in eleven medical centers. Journal of Clinical Microbiology, 44(8), 2816-2823. PMid:16891497. http://dx.doi.org/10.1128/JCM.00773-06

Costa, A. C. B., Rasteiro, V. M. C., Hashimoto, S. H., Araújo, C. F., Pereira, C. A., Junqueira, J. C., \& Jorge, A. O. C. (2012). Effect of erythrosine- and LED-mediated photodynamic therapy on buccal candidiasis infection of immunosuppressed mice and Candida albicans adherence to buccal epithelial cells. Oral Surgery, Oral Medicine, Oral Pathology and Oral Radiology, 114(1), 67-74. PMid:22727094. http://dx.doi.org/10.1016/j.000o.2012.02.002

Cowen, L.E., Sanglard, D., Howard, S., Rogers, D., \& Perlin, D. (2014). Mechanisms of antifungal drug resistance. Cold Spring Harbor Perspectives in Medicine, 5(7), a019752. PMid:25384768. http://dx.doi.org/10.1101/cshperspect.a019752

Djuretic, T., Wall, P. G., \& Nichols, G. (1997). General outbreaks of infectious intestinal diseases associated with milk and dairy products in England and Wales: 1992 to 1996. Communicable Disease Report, 7(3), 41-45. PMid:9080728.

Ellepola, A. N. B., \& Samaranayake, L. P. (1998a). Adhesion of oral C. albicans to human buccal epithelial cells following limited exposure to antifungal agents. Journal of Oral Pathology \& Medicine, 27(7), 325-332. PMid:9725570.

http://dx.doi.org/10.1111/j.1600-0714.1998.tb01964.x 
Ellepola, A. N. B., \& Samaranayake, L. P. (1998b). Adhesion of oral Candida albicans isolates to denture acrylic following limited exposure to antifungal agents. Archives of Oral Biology, 43(12), 999-1007. PMid:9877331. http://dx.doi.org/10.1016/S0003-9969(98)00075-2

Farias, F. F., Silva, W. R., Botelho, A. C. N., Hora, I. M. D. C., Kronenberger, G., \& Cruz, A. G. (2006). Microbiological quality of ice creams commercialized in some cities in the state of Rio de Janeiro, Brazil. International Journal of Dairy Technology, 59(4), 261-264. http://dx.doi.org/10.1111/j.1471-0307.2006.00278.x

Fernández-Ruiz, M., Guinea, J., Puig-Asensio, M., Zaragoza, Ó., Almirante, B., Cuenca-Estrella, M., Aguado, J. M., Candipop Project, Geih-Gemicomed - SEIMC, \& REIPI. (2017). Fungemia due to rare opportunistic yeasts: data from a population-based surveillance in Spain. Medical Mycology, 55(2), 125-136. PMid:27495321. http://dx.doi.org/10.1093/mmy/myw055

Fleet, G., \& Mian, M. A. (1987). The occurrence and growth of yeasts in dairy products. International Journal of Food Microbiology, 4(2), 145-155. http://dx.doi.org/10.1016/0168-1605(87)90021-3

Höfs, S., Mogavero, S., \& Hube, B. (2016). Interaction of Candida albicans with host cells: virulence factors, host defense, escape strategies, and the microbiota. Journal of Microbiology, 54(3), 149-169. PMid:26920876. http://dx.doi.org/10.1007/s12275-016-5514-0

Jadhav, A. S., \& Raut, P. D. (2014). Evaluation of microbiological quality of ice creams marketed in Kolhapur city, Maharashtra, India. International Journal of Current Microbiology and Applied Sciences, 3(9), 78-84.

Johann, S., Pizzolatti, M. G., Donnici, C. L., \& Resende, M. A. (2007). Antifungal properties of plants used in Brazilian traditional medicine against clinically relevant fungal pathogens. Brazilian Journal of Microbiology, 38(4), 632-637. http://dx.doi.org/10.1590/S1517-83822007000400010

Kanbakan, U., Çon, A. H., \& Ayar, A. (2004). Determination of microbiological contamination sources during ice cream production in Denizli, Turkey. Food Control, 15(6), 463-470. http://dx.doi.org/10.1016/S0956-7135(03)00131-2

Kimura, L. H., \& Pearsall, N. N. (1978). Adherence of Candida albicans to human buccal epthelial cells. Infection and Immunity, 21(1), 64-68. PMid:361571.

Kurtzman, C. P., Fell, J. W., \& Boekhout, T. (2011). The yeasts, a taxonomic study (5th ed.). Amsterdam: Elsevier.

Lachance, M. A., Bowles, J. M., Starmer, W. T., \& Barker, J. S. F. (1999). Kodamaea kakaduensis and Candida tolerans, two new ascomycetous yeast species from Australian Hibiscus flowers. Canadian Journal of Microbiology, 45(2), $172-177$. PMid:10380650. http://dx.doi.org/10.1139/w98-225

Lee, J. W., Kim, H. J., Yoon, Y., Kim, J.-H., Ham, J.-S., Byun, M.-W., Baek, M., Jo, C., \& Shin, M.-G. (2009). Manufacture of ice cream with improved microbiological safety by using gamma irradiation. Radiation Physics and Chemistry, 78(7-8), 593-595. http://dx.doi.org/10.1016/j.radphyschem.2009.03.016

Lima, G. B. L., Lucas, M. R. S., Rosa, C. A., \& Gomes, F. C. O. (2016). Analysis of the microbial quality of commercialized tropical fruit ice cream in Belo Horizonte, Brazil. Journal of Agroalimentary Processes and Technologies, 22(2), $79-86$.

Lopes, M.B., Soden, A., Martens, A. L., Henschke, P. A., \& Langridge, P. (1998). Differentiation and species identification of yeasts using PCR. International Journal of Systematic Bacteriology, 48(Pt 1), 279-286. PMid:9542098.

Lyon, J. P., \& Resende, M. A. (2006). Correlation between adhesion, enzyme production, and susceptibility to fluconazole in Candida albicans obtained from denture wearers. Oral Surgery, Oral Medicine, Oral Pathology, Oral Radiology, and Endodontics, 102(5), 632-638. PMid:17052640. http://dx.doi.org/10.1016/j.tripleo.2005.12.015

Maciel, N. O. P., Piló, F. B., Freitas, L. F. D., Gomes, F. C. O., Johann, S., Nardi, R. M. D., Lachance, M. A., \& Rosa, C. A. (2013). The diversity and antifungal susceptibility of the yeasts isolated from coconut water and reconstituted fruit juices in Brazil. International Journal of Food Microbiology, 160(3), 201-205. PMid:23290225.

http://dx.doi.org/10.1016/j.ijfoodmicro.2012.10.012

Martínez, E., Torres-Guerrero, E., Cortés, E., Tejada, D., \& Arenas, R. (2017). Cryptococcus laurentii infection in a patient with cutaneous leishmaniasis. International Journal of Dermatology, 56(3), 56-57. PMid:27666937.

http://dx.doi.org/10.1111/ijd.13329

Miceli, M. H., Díaz, J. A., \& Lee, S. A. (2011). Emerging opportunistic yeast infections. The Lancet. Infectious Diseases, 11(2), 142-151. PMid:21272794. http://dx.doi.org/10.1016/S1473-3099(10)70218-8National Center for Biotechnology Information NCBI. (2018). BLAST - Basic Local Alignment Search Tool. Retrieved in 2018, February 19, from https://blast.ncbi.nlm.nih.gov/Blast.cgi

Oliveira, V. K. P., Ruiz, L. S., Oliveira, N. A. J., Moreira, D., Hahn, R. C., Melo, A. S. A., Nishikaku, A. S., \& Paula, C. R. (2014). Fungemia caused by Candida species in a children's public hospital in the city of São Paulo, Brazil: study in the period 20072010. Revista do Instituto de Medicina Tropical de São Paulo, 56(4), 301-305. PMid:25076430. http://dx.doi.org/10.1590/S003646652014000400006

Perfect, J. R. (2006). Cryptococcus neoformans: the yeast that likes it hot. FEMS Yeast Research, 6(4), 463-468. PMid:16696642. http://dx.doi.org/10.1111/j.1567-1364.2006.00051.x

Pinhati, H. M., Casulari, L. A., Souza, A. C., Siqueira, R. A., Damasceno, C. M., \& Colombo, A. L. (2016). Outbreak of candidemia caused by fluconazole resistant Candida parapsilosis strains in an intensive care unit. BMC Infectious Diseases, 16, 433. PMid:27544427. http://dx.doi.org/10.1186/s12879-016-1767-9

Stratford, M. (2006). Food and beverages spoilage yeasts. In A. Querol \& G.H. Fleet (Eds.), Yeasts in food and beverages (pp. 335-379). Heidelberg: Springer-Verlag. http://dx.doi.org/10.1007/978-3-540-28398-0_11.

Sundh, I., \& Melin, P. (2011). Safety and regulatin 308 of yeasts used for biocontrol or biopreservation in the food or feed chain. Antonie van Leeuwenhoek, 99(1), 113-119. PMid:21086043. http://dx.doi.org/10.1007/s10482-010-9528-z 
Yeasts isolated from tropical fruit ice creams: diversity, antifungal susceptibility and adherence to buccal epithelial cells

Lima, G. B. L. et al.

Taj-Aldeen, S. J., AbdulWahab, A., Kolecka, A., Deshmukh, A., Meis, J. F., \& Boekhout, T. (2014). Uncommon opportunistic yeast bloodstream infections from Qatar. Medical Mycology, 52(5), 552-553. PMid:24934803.

Thomson, P., Mayayo, E., López-Fernández, L., Guarro, J., \& Capilla, J. (2017). Combined antifungal therapy against systemic murine infections by rare Cryptococcus species. Mycoses, 60(2), 112-117. PMid:27696562. http://dx.doi.org/10.1111/myc.12569

Tribst, A. A., Sant'Ana, A. S., \& Massaguer, P. R. (2009). Microbiological quality and safety of fruit juices: past, present and future perspectives. Critical Reviews in Microbiology, 35(4), 310-339. PMid:19863382. http://dx.doi.org/10.3109/10408410903241428

Trindade, R. C., Resende, M. A., Silva, C. M., \& Rosa, C. A. (2002). Yeasts associated with fresh and frozen pulps of Brazilian tropical fruits. Systematic and Applied Microbiology, 25(2), 294-300. PMid:12353886. http://dx.doi.org/10.1078/0723-202000089

Trofa, D., Gácser, A., \& Nosanchuk, J. D. (2008). Candida parapsilosis, an Emerging Fungal Pathogen. Clinical Microbiology Reviews, 21(4), 606-625. PMid:18854483. http://dx.doi.org/10.1128/CMR.00013-08

Villalobos, J. M., Castro, J. A., Avilés, A., Peláez, C., Somogyi, T., \& Sandoval, L. (2016). Candida parapsilosis: principal causa de candidemia en un hospital de referencia para adultos de Costa Rica. Revista Chilena de Infectologia, 33(2), 159-165. PMid:27314993. http://dx.doi.org/10.4067/S0716-10182016000200005

Westblade, L. F., Rostad, C. A., Hilinski, J. A., Stanley, T., Jerris, R. C., Wilkey, K., \& Pincus, D. H. (2015). Candida quercitrusa Candidemia in a 6-Year-Old Child. Journal of Clinical Microbiology, 53(8), 2785-2787. PMid:26063864.

http://dx.doi.org/10.1128/JCM.03657-14

Funding: This work was funded by the Conselho Nacional de DesenvolvimentoCientifico e Tecnológico (CNPq) and

Fundação do Amparo a Pesquisa do Estado de Minas Gerais

(FAPEMIG). 